This item was submitted to Loughborough's Research Repository by the author.

Items in Figshare are protected by copyright, with all rights reserved, unless otherwise indicated.

\title{
Microglia based Alzheimer therapy [Abstract]
}

PLEASE CITE THE PUBLISHED VERSION

https://doi.org/10.1016/j.freeradbiomed.2017.04.245

PUBLISHER

Elsevier

VERSION

SMUR (Submitted Manuscript Under Review)

\section{PUBLISHER STATEMENT}

This work is made available according to the conditions of the Creative Commons Attribution-NonCommercialNoDerivatives 4.0 International (CC BY-NC-ND 4.0) licence. Full details of this licence are available at: https://creativecommons.org/licenses/by-nc-nd/4.0/

\section{LICENCE}

CC BY-NC-ND 4.0

\section{REPOSITORY RECORD}

Arnold, Katrin, Claire Fabian, and Alexandra Stolzing. 2019. "Microglia Based Alzheimer Therapy [abstract]". figshare. https://hdl.handle.net/2134/26520. 
Microglia based Alzheimer therapy

Katrin Arnold, Claire Fabian, Alexandra Stolzing

Alzheimer's disease $(A D)$ is an age-related neurodegenerative disease associated with the formation of amyloid plaques, tau aggregation and oxidative/inflammatory damage. Microglia play an important role in the early phase of the disease and are known to be involved in AD progression. Senescent microglia accumulate in AD causing inflammation, neuronal damage and increasing the $A ß$ load due to a failing protein degradation system.

This study examines the transplantation of in vitro derived young microglia from wild type mice (aged $\sim 3$ months) to the brain of AD mice (APP/PS1 transgenic model: $>12$ months).

Microglia could be detected in the brain for four weeks after transplantation. Analysis of amyloid content shows a significant reduction as well as improved inflammation markers. Microglia and astrocyte morphology and activation status was analysed using histology. Changes in the short term memory of the recipient animals was analysed using a maze and found to be improved. Current analysis focuses on the quality and M1/M2 status of the microglia produced for transplantation to better understand if the therapeutic effect can be improved.

Keywords: Alzheimer, microglia, aging, inflammation 